\title{
Spondylo-megaepiphyseal-metaphyseal dysplasia
}

INSERM

\section{Source}

INSERM. (1999). Orphanet: an online rare disease and orphan drug data base. Spondylomegaepiphyseal-metaphyseal dysplasia. ORPHA:228387

Spondylo-meg aepiphyseal-metaphyseal dysplasia is a rare, genetic primary bone displasia characterized by disproportionate short stature with short, stiff neck and trunk and relatively long limbs, fing ers and toes (which may present flexion contractures), severe vertebral body ossification delay (with frequent kyknodysostosis), markedly enlarged round epiphyses of the long bones, absent ossification of pubic bones and multiple pseudoepiphyses of the short tubular bones in hands and feet. Neurological manifestations resulting from cervical spine instability may be observed. 